\title{
Nienaturalistyczne metodologie we współczesnej praktyce
}

W niektórych dziedzinach istnieją już alternatywy dla naturalizmu metodologicznego. Jednakże niewiele osób spoza danej dziedziny zna te alternatywy lub wie, jak są wykorzystywane. Niekiedy nawet sami przedstawiciele tych dziedzin stosują te nienaturalistyczne metodologie, nie wiedząc, że nie są one spójne $\mathrm{z}$ naturalizmem metodologicznym. W artykule dokonujemy krótkiego przeglądu dziedzin, w których — zgodnie z naszą wiedzą — występują metodologie niezależne od naturalizmu.

\section{Wprowadzenie}

Chociaż naturalizm metodologiczny stał się prawdziwym standardem $\mathrm{w}$ wielu dziedzinach, istnieją liczne poddziedziny różnych dyscyplin, które funkcjonują $\mathrm{w}$ zgodzie $\mathrm{z}$ innymi regułami. W niektórych przypadkach odstępstwo od naturalizmu metodologicznego nie jest wyrażone otwarcie i przedstawi-

Jonathan BartLett, M.T.S. — The Blyth Institute, e-mail: jonathan.bartlett@blythinstitute. org; Eric Holloway - The Blyth Institute, e-mail: eric.holloway@blythinstitute.org.

(C) Copyright by Jonathan Bartlett, Eric Holloway, Blyth Institute Press, Dariusz Sagan \& Filozoficzne Aspekty Genezy.

* Jonathan Bartlett and Eric Holloway, „Other Non-Naturalistic Methodologies in Modern Practice", w: Jonathan Bartlett and Eric Holloway (eds.), Naturalism and Its Alternatives in Scientific Methodologies: Proceedings of the $\mathbf{2 0 1 6}$ Conference on Alternatives to Methodological Naturalism, Blyth Institute Press, Broken Arrow, Oklahoma 2017, s. 257-268. Za zgodą Autorów i Wydawnictwa z języka angielskiego przełożył: Dariusz SAGAN. 
ciele danej dziedziny mogą nie być tego świadomi. W innych przypadkach odstępstwo to jest określone jasno i wyraźnie.

Cele tego artykułu są następujące:

1. pokazać, że badania akademickie mogą być efektywne poza ramami naturalizmu

2. zachęcić do tego, by nienaturalistyczne podejścia z pewnych dziedzin inspirowały podobne techniki w innych dziedzinach

3. pokazać, że nienaturalistyczny sposób myślenia nadaje większy sens dziedzinom stosującym nienaturalizm nieświadomie i że ujawnienie ich nienaturalistycznych aspektów może prowadzić do pogłębienia uzyskiwanych przez nie wyników

Miejmy nadzieję, że ten artykuł da inspirację i dostarczy idei, które pomogą popchnąć do przodu program nienaturalistyczny.

\section{Dualizm metodologiczny w austriackiej ekonomii}

Jedną z dziedzin, w których naturalizm metodologiczny spotkał się z jawnym wyzwaniem, jest ekonomia. Pod koniec dziewiętnastego wieku w ekonomii zaczęto dyskutować nad rolą historii i rolą jednostek. Menger ${ }^{1}$ krytykował tak zwaną „historyczną” szkołę myślenia, która uznawała, że działalność ekonomiczna jest $\mathrm{w}$ całości rezultatem wcześniejszej historii. Można ją postrzegać po prostu jako konieczne następstwo tego, co wydarzyło się wcześniej. Menger uważał natomiast, że ekonomię napędzają sytuacje i wybory jednostek (zarówno jako indywiduów, jak też jako wspólnot). Według Mengera tak zwana szkoła „historyczna” nie rozumiała historii i chociaż historia wykazywała pewne podobieństwa wzorców i funkcjonowała $w$ ramach użytecznych systemów teoretycznych, uproszczony pogląd szkoły historycznej wyolbrzymiał stopień podobieństwa grupowych wzorców ekonomicznych.

\footnotetext{
${ }^{1}$ Por. Carl Menger, Investigations into the Method of the Social Sciences with Special Reference to Economics, trans. Francis J. Nock, New York University Press, New York and London (1883) 1985.
} 
Menger zauważył, że różne części społeczeństwa można podzielić na elementy porównywalne do organizmów i elementy porównywalne do mechanizmów. Pierwsze są zasadniczo niemożliwe do opisania przez naukę ekonomii, a drugie mogą być ujęte ilościowo. Tak więc ludzie mogą wykorzystać swoją wolę do osiągania celów poprzez tworzenie mechanizmów, zaś grupy ludzi mogą wykorzystać swoją kolektywną wolę do osiągania celów poprzez tworzenie mechanizmów społecznych. Ekonomia może należycie mierzyć wpływ i skutki działania mechanizmów ustanowionych przez akty woli, ale nie ma dostępu do pierwotnych wyborów, które doprowadziły do ich wytworzenia.

Ideę oddzielenia woli od mechanizmu w bardziej formalny sposób zdefiniował von Mises w jednej ze swoich książek. ${ }^{2} \mathrm{~W}$ książce tej von Mises definiuje stanowisko, które nazwał dualizmem metodologicznym. Zgodnie z nim ludzkie wybory są nieredukowalne do zjawisk fizycznych i należy uznać je za byty pierwszego rzędu. Ponadto, gdyby nawet ludzkie wybory dało się zredukować do innych zjawisk, to przy naszym aktualnym stanie wiedzy nie mamy do tego dostępu, a więc z metodologicznego punktu widzenia należy uznać, że wybór jest bytem nieredukowalnym. Jak wyjaśnia von Mises:

Konkretne sądy wartościujące i określone ludzkie działania nie poddają się dalszej analizie. Możemy z powodzeniem uznać lub przyjąć, że zależą one całkowicie od swoich przyczyn i są przez nie uwarunkowane. Dopóki jednak nie dowiemy się, w jaki sposób zewnętrzne zdarzenia - fizyczne i psychologiczne - powodują powstawanie w ludzkim umyśle określonych myśli i aktów woli, których rezultatem są konkretne działania, dopóty nie przezwyciężymy dualizmu metodologicznego. Przy obecnym stanie wiedzy podstawowe twierdzenia pozytywizmu, monizmu i panfizykalizmu są tylko metafizycznymi postulatami pozbawionymi jakichkolwiek naukowych podstaw. Sa pozbawione znaczenia i bezużyteczne dla badań naukowych. Rozum i doświadczenie wskazują na istnienie dwóch odrębnych sfer: zewnętrznego świata zjawisk fizycznych, chemicznych i fizjologicznych oraz wewnętrznego świata myśli, uczuć, ocen i celowego działania. W obecnym stanie wiedzy nie da się wskazać pomostu łączącego te dwie sfery. Zdarza się, że identyczne zdarzenia zewnętrzne wywołują różne reakcje człowieka; bywa też tak, że dwa różne zdarzenia zewnętrzne prowadzą do takiej samej reakcji. Nie wiemy, dlaczego tak się dzieje.

\footnotetext{
${ }^{2}$ Por. Ludwig von Mises, Ludzkie dzialanie. Traktat o ekonomii, przeł. Witold Falkowski, Biblioteka Klasyków Ekonomii, Instytut Ludwiga von Misesa, Warszawa 2007.
} 
W tej sytuacji pozostaje nam jedynie powstrzymanie się od oceny podstawowych twierdzeń monizmu i materializmu. Możemy wierzyć lub nie, że pewnego dnia nauki przyrodnicze wyjaśnią powstawanie określonych pojęć, sądów wartościujących i działań w taki sam sposób, w jaki wyjaśniają powstawanie związku chemicznego jako koniecznego i nieuniknionego wyniku połączenia pierwiastków. Zanim to nastąpi, zmuszeni jesteśmy zaakceptować dualizm metodologiczny. ${ }^{3}$

W związku z tym, podczas gdy naturalizm metodologiczny zakłada, że wszystkie zdarzenia mają przyczyny redukowalne do mechanizmów, dualizm metodologiczny jako swoje metodologiczne założenie przyjmuje ideę, że ludzka wola nie jest redukowalna $\mathrm{w}$ ten sposób. Podobnie do naturalizmu metodologicznego warunek ten nie narzuca bezpośrednio praktykowi metafizycznej perspektywy dualizmu, lecz jest jedynie metodologiczną wskazówką. Taka metodologia z pewnością jest jednak wygodniejsza dla kogoś, kto wyznaje pasującą do niej metafizykę.

W ostatnich latach ten punkt widzenia został rozszerzony w pracach Gildera ${ }^{4}$ oraz Thiela i Mastersa. ${ }^{5}$ Gilder rozszerzył dualizm metodologiczny, dodając nowy składnik - ludzką kreatywność. Podczas gdy austriacka ekonomia skupia się na ludzkich wyborach, Gilder kładzie nacisk na kreatywność wymaganą dla wzrostu makroekonomicznego. Według Gildera typowe modele makroekonomiczne, które pomijają ludzką kreatywność i próbują zredukować działanie ekonomii do jakiegoś równania, zupełnie mijają się z celem. Ekonomia nie jest wielkim równaniem, do którego można wprowadzić odpowiednie wartości i uzyskać wzrost ekonomiczny. Bagus ${ }^{6}$ pokazuje, że postrzeganie ekonomii w ten (naturalistyczny) sposób doprowadziło do katastrof ekonomicznych w wiekach dwudziestym i dwudziestym pierwszym.

\footnotetext{
${ }^{3}$ von Mises, Ludzkie dzialanie... [przyp. thum. - cytat podaję za fragmentem przekładu polskiego dostępnym w Internecie: http://mises.pl/pliki/upload/HumanAction_rozdz1-3.pdf (12.04. 2017)].

${ }^{4}$ Por. George Gilder, Knowledge and Power: The Information Theory of Capitalism and How It Is Revolutionizing our World, Regnery Publishing, Washington, DC. 2013.

${ }^{5}$ Por. Peter Thiel and Blake Masters, Zero to One: Notes on Startups, or How to Build the Future, Crown Business, New York 2014.

${ }^{6}$ Por. Phillip Bagus, „Methodological Naturalism in the Austrian School of Economics”, 2016 Conference on Alternatives to Methodological Naturalism 2016.
} 
Gilder wskazuje, że wzrost ekonomiczny zachodzi, gdy pozwoli się na rozkwit indywidualnej kreatywności, która nie jest redukowalna do równań, i zapewni się jej odpowiednie wsparcie. Jawnym celem ekonomii nie jest zatem wzrost ekonomiczny (ponieważ nie potrafimy, w zasadzie, przewidzieć kreatywności), lecz zapewnienie warunków umożliwiających najskuteczniejsze działanie kreatywności — zapewnienie jej dostatecznej wolności, stabilizacji i wsparcia. Innymi słowy, każda próba podyktowania działań ekonomii jest z gruntu chybiona. Należy natomiast przygotować ekonomię do lepszego pielęgnowania i uwzględniania nieprzewidywalnej kreatywności uczestników procesu ekonomicznego.

Ten pogląd na ekonomię zasadza się więc na rozróżnieniu między tym, co można wiedzieć na podstawie mechanizmów (to jest równań), a tym, co wymaga niemechanicznego wkładu (to jest kreatywności).

Thiel i Masters rozszerzają tę ideę jeszcze bardziej — na mikroekonomię. W swojej książce Thiel dostrzega różnicę między tym, co można zrobić indywidualnie na podstawie ludzkiego poznania, a tym, co można zrobić za pośrednictwem algorytmu (czyli równania). Thiel stwierdza, że:

komputery różnią się od ludzi znacznie bardziej niż dowolna para ludzi od siebie. Ludzie i maszyny są dobrzy w fundamentalnie innych sprawach. Ludzie mają intencjonalność - tworzymy plany i podejmujemy decyzje w skomplikowanych sytuacjach. Gorzej idzie nam odnajdywanie sensu w ogromnych ilościach danych. Komputery są naszym dokładnym przeciwieństwem: prześcigają się w wydajności przetwarzania danych, ale mają duże trudności w formułowaniu podstawowych sądów, które ludziom nie sprawiają najmniejszego problemu. [...]

W 2012 roku jeden z superkomputerów [Google'a] trafił na nagłówki gazet, gdy po przeskanowaniu 10 milionów miniaturek filmików z YouTube'a nauczył się rozpoznawać kota z 75\% dokładnością. Wydaje się robić to wrażenie — dopóki nie przypomnimy sobie, że przeciętny czterolatek jest w stanie robić to bezbłędnie. Kiedy tani laptop bije na głowę najbystrzejszego matematyka w pewnych zadaniach, ale nawet superkomputer mający 16000 procesorów nie może przewyższyć dziecka $w$ innych, to można powiedzieć, że ludzie i komputery nie są tylko mniej lub bardziej potężni od siebie nawzajem — są kategorycznie odmienni. ${ }^{7}$

\footnotetext{
${ }^{7}$ Thiel and MAsters, Zero to One..., s. 143-144.
} 
Ta kategoryczna różnica między ludźmi a komputerami służy Thielowi do uznania, że jednym z najlepszych sposobów na otrzymanie dużych zysków jest zidentyfikowanie aksjomatów, o których inni ludzie nie mają pojęcia. Thiel ilustruje to pytaniem: „W jakiej ważnej kwestii zgadza się z tobą bardzo niewielu ludzi?" 8

Według Thiela do wzrostu ekonomicznego prowadzi tworzenie nowych aksjomatów. Biznesy oparte na istniejącej wiedzy i ideach posuwają ekonomię od 1 do $N$, lecz aksjomat może posunąc ekonomię od 0 do 1 . Innymi słowy, nowe aksjomaty umożliwiają stworzenie zupełnie nowych obszarów rozwoju ekonomicznego. Gdy już jakiś aksjomat zostanie utworzony, mogą go powielać i wykorzystywać inni uczestnicy procesu ekonomicznego, ale głównym motorem wzrostu jest uprzednie stworzenie aksjomatu. Na ideę tę wskazywały również wyniki badań teoretycznych przedstawionych na konferencji „Engineering and Metaphysics" [Inżynieria i metafizyka]. ${ }^{9}$

Jak wykazali Robertson ${ }^{10}$ i Bartlett, ${ }^{11}$ tworzenia nowych aksjomatów nie można pojmować w sposób naturalistyczny. Wygląda więc na to, że w ekonomii metodologie nienaturalistyczne pozwalają lepiej rozpoznawać rodzaje obserwowanych zjawisk i lepiej rozumieć związki między nimi.

\section{Ludzka komputacja i sztuczna sztuczna inteligencja}

Przywiązanie do metodologii to miecz obosieczny. Z jednej strony może wzmocnić punkt widzenia, który ignoruje fakty, ale z drugiej - metodologia oparta na faktach może wzmocnić perspektywę sprzeczną z rządzącym paradyg-

\footnotetext{
${ }^{8}$ Thiel and Masters, Zero to One..., s. 12.

${ }^{9}$ Por. Jonathan Bartlett, „Using Turing Oracles in Cognitive Models of Problem-Solving”, w: Jonathan Bartlett, Dominic Halsmer, and Mark Hall (eds.), Engineering and the Ultimate: An Interdisciplinary Investigation of Order and Design in Nature and Craft, Blyth Institute Press, Broken Arrow, Oklahoma 2014, s. 99-122; Jonathan BartletT, „Measuring Software Complexity Using the Halting Problem", w: Bartlett, Halsmer, and Hall (eds.), Engineering and the Ultimate..., s. 123-130.

${ }^{10}$ Por. Douglas S. Robertson, „Algorithmic Information Theory, Free Will, and the Turing Test”, Complexity 1999, vol. 4, no. 3, s. 17-34.

${ }^{11}$ Por. Bartlett, „Using Turing Oracles...”.
} 
matem. Widzieliśmy to w przypadku ekonomii, gdzie ekonomiści z konieczności muszą przyjmować dualistyczną perspektywę dotyczącą ludzkiej i mechanicznej sfery ekonomii.

Informatyka również stoi w obliczu konieczności przyjęcia dualizmu metodologicznego. W erze rozmaitych technologii społecznych, takich jak komputer osobisty, Internet i Facebook, ludzie stają się zarówno konsumentami, jak i produktami. Informatycy gołosłownie deklarują poparcie dla monizmu informatyki, Ogólnej Sztucznej Inteligencji (General Artificial Intelligence — GAI), ale są zgodni, że dopóki nie nastanie epoka GAI, użyteczniejsze jest uwzględnianie czynnika ludzkiego. Obietnica GAI okazała się wielkim rozczarowaniem, ponieważ jej spełnienie jest „,bliskie” już od ponad pół wieku, kiedy to Alan Turing wymyślił maszynę Turinga.

Dualizm metodologiczny w informatyce szczególnie uwidacznia się w powstaniu przedsięwzięć ludzkiej komputacji (Human Computation - HC) i sztucznej sztucznej inteligencji (Artificial Artificial Intelligence - AAI). ${ }^{12}$ Ludzka komputacja to posługiwanie się rozwiązaniami podsuniętymi przez człowieka w zadaniach, dla których nie jest znane żadne rozwiązanie algorytmiczne. Zadania te są zwykle mikrozadaniami, które mogą być szybko rozwiązane przez większość użytkowników Internetu o zerowym lub minimalnym wytrenowaniu. Przykłady takich zadań to identyfikowanie obiektów w obrazach, rozpoznawanie części mowy w zdaniach i przepisywanie zapisów audio. Zadania te są czymś banalnym dla dziecka, lecz są zbyt trudne dla najwydajniejszych superkomputerów.

Mikrozadania sumowane są algorytmicznie i/lub przy pomocy dalszego wkładu człowieka, ${ }^{13}$ a powstający w ten sposób system hybrydowy nazywany jest sztuczną sztuczną inteligencją. Wydaje się, że system algorytmicznie rozwiązuje dany problem, ponieważ sprawia wrażenie tradycyjnej sztucznej inteli-

\footnotetext{
${ }^{12}$ Por. „Artificial Artificial Intelligence”, The Economist 8 January 2006, http://www.econo mist.com/node/7001738 (13.04.2017).

${ }^{13}$ Por. Peng DaI, Mausam, and Daniel S. WeLD, ,Artificial Intelligence for Artificial Artificial Intelligence", Proceedings of the Twenty-Fifth AAAI Conference on Artificial Intelligence 2011, https://www.aaai.org/ocs/index.php/AAAI/AAAI1 1/paper/viewFile/3775/4051 (13.04.2017).
} 
gencji, ale jego wewnętrzne działanie jest zasadniczo zależne od ciągłej ingerencji człowieka.

Pojęcie ludzkiej komputacji po raz pierwszy przykuło uwagę społeczeństwa dzięki pionierskiemu projektowi Luisa von Ahna, czyli popularnej obecnie technice CAPTCHA, ${ }^{14}$ oraz przełomowym odkryciom naukowym projektu Foldit. Jedno z najbardziej znanych takich odkryć trafiło na nagłówki gazet, ponieważ amatorzy zastosowali inżynierię odwrotną do krystalicznej struktury proteazy HIV, a więc dokonali wyczynu, który znajdował się poza zasięgiem najwydajniejszych superkomputerów i najlepszych ekspertów. ${ }^{15}$

Amazon, zachęcony tymi sukcesami, uruchomił publiczną platformę mikrozadaniową, nazwaną Mechanical Turk [Mechaniczny Turek] (od „Turka”, osiemnastowiecznego pierwowzoru $\mathrm{HC}$ ), powszechnie wykorzystywaną przez badaczy akademickich i firmy internetowe. ${ }^{16}$ Ludzka komputacja nie cieszy się jednak tylko niszowym zainteresowaniem. Firmy, takie jak Google, Facebook i Microsoft, są tak bardzo uzależnione od HC przy tworzeniu swoich algorytmów, że stworzyły własne wewnętrzne platformy. ${ }^{17} \mathrm{HC}$ może być paliwem zasilającym całą rewolucję internetową. Na wszystkich platformach internetowych powszechnie szuka się przecież właśnie informacji pochodzących od człowieka.

Patrząc z perspektywy czasu, na ironię zakrawa to, że sztuczna inteligencja zyskuje jeszcze większą reklamę, gdy coraz wyraźniejsza staje się konieczność przyjęcia dualizmu metodologicznego. AI jest następstwem naturalizmu metodologicznego w informatyce, ponieważ polega na redukowaniu umysłu do hard-

\footnotetext{
${ }^{14}$ Por. Edith Law and Luis von AHn, Human Computation, Morgan and Claypool 2011.

${ }^{15}$ Por. Firas Khatib, Frank DiMaio, Seth Cooper, Maciej Kaźmierczyk, Mirosław Gilski, Szymon Krzywda, Helena Zabrańska, Iva Pichova, James Thompson, Zoran Popović, Mariusz JASKÓLSKI, and David BAKER, „Crystal Structure of a Monomeric Retroviral Protease Solved by Protein Folding Game Players", Nature Structural \& Molecular Biology 2011, vol. 18, no.10, s. $1175-1177$.

${ }^{16}$ Por. Kristen Millares Bolt, „Amazon Creates Artificial Artificial Intelligence”, Seattle Pi 3 November 2005, http://www.seattlepi.com/business/article/Amazon-creates-artificialartificial-in telligence-1186698.php (13.04.2017).

${ }^{17}$ Por. Adam Marcus and Aditya Parameswaran, „Crowdsourced Data Management: Industry and Academic Perspectives”, Foundations and Trends in Databases 2015, vol. 6, no. 1-2, s. 1161.
} 
ware'u. Mimo to, jak wskazuje Yogi Berra w powszechnie przypisywanej mu wypowiedzi: „W teorii nie ma różnicy między teorią a praktyką. W praktyce jest". ${ }^{18}$ To, że praktycy muszą porzucić naturalizm metodologiczny i zastąpić go dualizmem, aby mogli wykonywać swoją pracę, daje nam sygnał, że metodologiczna otwartość umysłu jest bardziej pragmatyczna niż metodologiczny dogmatyzm.

\section{Filozofia moralna w analizie transakcji internetowych}

Jednym z głównych problemów internetowych platform komercyjnych jest kwestia wykrywania fałszywych płatności. To, czy firmy internetowe są dochodowe czy nie, często zależy od zdolności platformy do zapobiegania fałszywym transakcjom lub do wykrywania ich. Internet stwarza szczególnie problematyczną przestrzeń dla oszustw, ponieważ w Internecie nie ma bariery między oszustami a firmami padającymi ich ofiarą. Podczas gdy w świecie fizycznym ilość możliwych oszustw w danym miejscu jest ograniczona przez liczbę osób gotowych do dokonania oszustwa, w Internecie żadna podobna naturalna bariera nie istnieje. $\mathrm{Z}$ tego powodu wykrywanie oszustw i zapobieganie im stało się bardzo problematycznym obszarem dla powszechnie znanych komercyjnych serwisów internetowych.

Książka Start-Up Nation [Naród start-upów] ${ }^{19}$ opowiada historię dotyczącą tego, jak przedsiębiorcza firma Fraud Sciences posłużyła się filozofią moralną do szybkiego i dokładnego wykrycia fałszywych transakcji w serwisie PayPal. Tak opisuje ona spotkanie Shvata Shakeda z Fraud Sciences ze Scottem Thompsonem z PayPal:

„Jaki macie model, Shvat?" — zapytał Thompson, chcąc mieć spotkanie już za sobą. Wiercąc się trochę jak ktoś, kto nie przygotował dobrze swojej jednominutowej „pre-

\footnotetext{
${ }^{18}$ Początkowo cytat ten został przypisany anonimowemu źródłu przez Savitcha, który przy padkowo usłyszał go na pewnej konferencji informatycznej (por. Walter J. SAvitch, PASCAL: An Introduction to the Art and Science of Programming, Benjamin-Cummings Publishing Company, San Francisco 1984), ale później mówiono, że jest to wypowiedź Yogiego Berry (mało prawdopodobne) lub Jana L. van de Snepscheuta (bardziej prawdopodobne).

${ }^{19}$ Por. Dan Senor and Saul Singer, Start-up Nation: The Story of Israel's Economic Miracle, Twelve, New York 2011.
} 
zentacji windowej”, Shvat zaczął cicho: „Nasz pomysł jest prosty. Wierzymy, że w świecie istnieje podział na ludzi dobrych i złych, a sposobem na rozprawienie się z oszustwami jest odróżnienie tych ludzi w Internecie".

Thompson nie dał po sobie poznać rozczarowania. Tego było za wiele, nawet jeśli chodziło tylko o przetestowanie oprogramowania. Zanim Thompson zaczął pracę w serwisie PayPal, był głównym kierownikiem w Visie, gigancie kart kredytowych, a więc $w$ jeszcze większej firmie, która miała nie mniejszą obsesję na punkcie zwalczania oszustw. Zadaniem dużej części zespołu w większości firm kart kredytowych i sprzedawców internetowych jest sprawdzanie nowych klientów, zwalczanie oszustw i identyfikowanie złodziei, ponieważ to $\mathrm{w}$ tym obszarze określane są marginesy zysku, a zaufanie do klientów jest budowane lub tracone.

W Visie i partnerujących jej bankach nad zwalczaniem oszustw pracują dziesiątki tysięcy ludzi. W PayPalu osób starających się być o krok przed oszustami jest dwa tysią$\mathrm{ce}, \mathrm{w}$ tym około pięćdziesięciu najlepszych inżynierów z doktoratami. A teraz ten dzieciak mówi o „dobrych i złych ludziach”, tak jakby jako pierwszy odkrył ten problem.

„Brzmi nieźle” — powiedział Thompson z niewielkim przekonaniem. „Jak to robisz?”

„Dobrzy ludzie zostawiają ślady w Internecie - cyfrowe odciski palców - bo nie mają nic do ukrycia" - kontynuował Shvat swoim specyficznie akcentowanym angielskim. „Źli ludzie nie zostawiają śladów, bo próbują coś ukryć. Szukamy jedynie śladów. Jeśli da się je znaleźć, to można zminimalizować ryzyko do akceptowalnego poziomu i potraktować to jako gwarancję. To naprawdę takie proste".

Thompson zaczął myśleć, że ten facet o dziwnym imieniu przybył nie z innego kraju, tylko z innej planety. Czy on nie wie, że zwalczanie oszustw to mozolny proces sprawdzania kontekstów, przedzierania się przez gąszcz historii kredytowych, tworzenia wyrafinowanych algorytmów do ustalania wiarygodności? Nie poszlibyśmy do NASA, by powiedzieć: „Po co budować te wszystkie skomplikowane statki kosmiczne, skoro wystarczy proca?" 20

Ostatecznie okazało się, że model opracowany przez Fraud Sciences jest szybszy i dokładniejszy niż system PayPala i to przy użyciu mniejszej ilości danych. Fraud Sciences udało się wypaść o 17\% lepiej w najbardziej kłopotliwej kategorii PayPala — dobrych klientów błędnie oznaczanych jako złych.

Zaszokowało to kierowników PayPala dokładnie z tego powodu, że PayPal miał najbardziej zaawansowany na świecie system wykrywania oszustw,

\footnotetext{
${ }^{20}$ SEnOr and Saul Singer, Start-up Nation..., s. 24-25.
} 
a mimo to mistrzowie danych tej firmy łatwo przegrali z bezimiennym nowicjuszem mówiącym o „dobrych” i ,złych” ludziach.

Tym, co pozwoliło przedstawicielom Fraud Sciences na lepszą analizę transakcji, nie była umiejętność tworzenia komputerowych modeli oszustwa, lecz zastosowanie filozofii moralnej, dzięki której ustalili, jakie dane są im potrzebne. Potrafili przyjąć pewną ważną prawdę o złu — że lubi skrywać się w ciemności - i dlatego byli w stanie zrozumieć, co pominęły wszystkie inne modele. Innymi słowy, jeśli ktoś żyje w pełnym świetle dnia, to jest mało prawdopodobne, że będzie popełniać oszustwa.

Duże firmy nie mają innego wyjścia, jak działać na podstawie danych i algorytmów. Jednakże historia Fraud Sciences uzmysławia, że przyznawanie filozofii pierwszeństwa w rozwiązywaniu problemów może często przynieść wymierne korzyści.

\section{Zasady inżynieryjne w biologii systemowej}

W wiekach dziewiętnastym i dwudziestym biologowie w coraz to większym stopniu badali organizmy przy użyciu metodologii naturalistycznych. Ponieważ naturalizm łączy wszystkie zdarzenia za pomocą historycznego układu odniesienia, więc sama biologia całkowicie została uwikłana w historyczny układ odniesienia ewolucjonizmu. I skoro naturalizm rozkłada wszystkie zdarzenia na ich części składowe, więc to samo przypadło w udziale również biologii.

Zatem w wiekach dziewiętnastym i dwudziestym biologię cechowało odniesienie do historii ewolucyjnej i redukcjonizmu fizyko-chemicznego. Ta pierwsza próbowała wyjaśniać każdą część organizmu historycznymi przypadkami i presjami selekcyjnymi, które miały udział w powstaniu tego organizmu. Ten drugi usiłował wyjaśniać każde działanie organizmu mniejszymi działaniami na coraz to niższych poziomach.

Nie chodzi o to, że koniecznie musiało rodzić to problemy. W istocie wieki dziewiętnasty i dwudziesty mogą chlubić się wielkimi osiągnięciami w obu tych liniach badań. Problem, jak zawsze, polega na tym, że poszukuje się pewnych typów przyczyn, a ignoruje się inne. Jak mówi powiedzenie: „Gdy masz tylko 
młotek, wszystko zaczyna przypominać gwóźdź". To efekt niewolniczego stosowania Brzytwy Ockhama wówczas, gdy nie jest to najlepsze rozwiązanie.

Carl Woese rozmyślał nad problemami związanymi z tym sposobem uprawiania biologii:

Sukces biologii molekularnej w minionym wieku związany jest wyłącznie z rozpatrywaniem pewnych problemów stawianych przez biologię (gen i natura komórki) i rozpatrywaniem ich z czysto redukcjonistycznej perspektywy. Przyniosło to zdumiewające efekty. Inne problemy - ewolucja i natura formy biologicznej — biologia molekularna postanowiła zignorować, albo zupełnie ich nie dostrzegając, albo uznając je za błahe, za rezultaty historycznego przypadku, zasadniczo niewythumaczalne i nieistotne dla naszej wiedzy biologicznej. Powinno to skłaniać do myślenia. ${ }^{21}$

Woese przyjmuje naturalizm metodologiczny i nie sugeruje odstępstwa od niego. Mimo to interesujące jest, że okres, w którym pomijano wielkie pytania biologii na rzecz pytań małych, był także erą najbardziej zdominowaną przez naturalizm metodologiczny.

Nowa nauka biologii systemowej to próba uprawiania biologii bez ograniczeń historycyzmu i redukcjonistycznych mechanizmów. W biologii systemowej układy biologiczne analizowane są jako holistyczne jednostki, z mniejszym naciskiem na historię. Specjaliści w dziedzinie biologii systemowej poszukują najogólniejszych zasad projektowych w układach biologicznych. Biologia systemowa analizuje biologię $\mathrm{w}$ wielu skalach, pokazując, jak wzorce $\mathrm{w}$ jednej skali wchodzą w interakcje $\mathrm{z}$ wzorcami w innej skali.

W odróżnieniu od naturalizmu, który faworyzuje przyczyny z najmniejszej skali i ich mechanikę, biologia systemowa faworyzuje zasady projektowe, zgodnie z którymi układy funkcjonują. Naturalizm faworyzuje też wyjaśnienia układów odwołujące się do historycznych przyczyn, takich jak ewoluowanie z wcześniejszych układów, a biologia systemowa faworyzuje wyjaśnienia holistyczne koncentrujące się na celach badanych układów.

Wydaje się więc, że mimo iż biologia systemowa nie wyklucza naturalizmu metodologicznego w sposób jawny, w perspektywie nienaturalistycznej badania

\footnotetext{
${ }^{21}$ Carl R. Woese, „A New Biology for a New Century”, Microbiology and Molecular Biology Reviews 2004, vol. 68, no. 2, s. 175 [173-186].
} 
biologii systemowej są bardziej spójne i zrozumiałe. W fizyce nie występuje kategoria „zasad projektowych”, a w związku z tym jeśli zostanie znaleziona jakaś zasada projektowa, to $\mathrm{w}$ jakim sensie może się ona wpisywać w naturalizm? Jeżeli jednak projekt zostanie uznany za zasadę przyczynową samą w sobie i samą z siebie (wbrew naturalizmowi), to nada to większy sens temu, co dzieje się w biologii systemowej. Jak wskazuje Nelson, ${ }^{22}$ w układach zaprojektowanych znajomość celu projektu bezpośrednio rzutuje na zagadnienie, jak zaprojektowano jego działanie.

Nelson dostrzegł dodatkową zasadę, którą nazwał wnioskowaniem z konieczności funkcjonalnej na poziomie systemu. Biologowie często mają do czynienia z układami, których działanie znane jest tylko częściowo. Na ogół istnieją dwie metody wnioskowania o nieznanych częściach układów biologicznych historyczna i dotycząca konieczności funkcjonalnej na poziomie systemu. Nelson wskazuje, że w perspektywie historycznej biologowie często czynią założenia co do działania systemów, związane $\mathrm{z}$ ich wiedzą na temat historii naturalnej systemu i rodzajów zmian, do jakich dobór naturalny (lub inny mechanizm ewolucyjny) doprowadził w danym układzie biologicznym. Z drugiej strony wnioskowanie z konieczności funkcjonalnej na poziomie systemu wykorzystuje najogólniejsze wymogi projektowe układu w analizie nieznanych części. Innymi słowy, jeśli wyobrazimy sobie, że dysponujemy najogólniejszym opisem układu biologicznego, często możemy wnioskować o nieznanych częściach na podstawie tego opisu. Ta metoda wnioskowania faworyzuje projekt, a nie historycyzm i oddolne mechanizmy, czyli filary naturalizmu. Nelson pokazuje więc, że gdy wnioskowania $\mathrm{z}$ historii i konieczności funkcjonalnej na poziomie systemu znajdują się w konflikcie, ten drugi rodzaj wnioskowania niemal zawsze na dłuższą metę okazuje się prawidłowy.

Jeszcze większy problem dla naturalizmu wskazuje zespół Halsmera, ${ }^{23}$ wedle którego nauki biologiczne odnoszą największe sukcesy, gdy wykonują ten

\footnotetext{
${ }^{22}$ Por. Paul Nelson, „Design Triangulation”, 2016 Conference on Alternatives to Methodological Naturalism 2016, film: https://www.youtube.com/watch? $=$ rNY_i1kJAnk (13.04.2017).

${ }^{23}$ Por. Dominic Halsmer, Michael Gewecke, Rachelle Gewecke, Nate Roman, Tyler Todd, and Jessica FitzGerald, „Reversible Universe: Implications of Affordance-Based Reverse Engineering of Complex Natural Systems", w: Bartlett, Halsmer, and Hall (eds.), Engineering and the Ultimate..., s. 11-38.
} 
sam rodzaj pracy, co inżynierowie stosujący inżynierię odwrotną do maszyn konstruowanych przez innych projektantów. Halsmer sugeruje, że większe uwypuklenie roli inżynierii odwrotnej w biologii — dzięki otwartemu studiowaniu i uznawaniu literatury poświęconej inżynierii odwrotnej — pomogłoby udoskonalić metody pracy biologów.

\section{Zakończenie}

Jak da się zauważyć, wiele obszarów badań może odnieść i odnosi korzyści z przyjmowania innej perspektywy niż naturalizm metodologiczny. Zwykle przyjmuje to formę jawnego uznawania zjawisk niefizycznych za realne zasady przyczynowe pierwszego rzędu. W ekonomii i informatyce sprowadza się to do uznania ludzkich wyborów i kreatywności za fundamentalne zasady przyczynowe. $\mathrm{W}$ analizie transakcji internetowych jest to przyjęcie, że kategorie filozofii moralnej są ważniejsze i bardziej fundamentalne niż gromadzone dane. W biologii oznacza to uznanie, że zasady projektowe są bardziej podstawowe niż historia lub fizyczne redukcje.

W niektórych przypadkach otwarcie przyjmuje się, że ten rodzaj badania wykracza poza naturalizm metodologiczny, a w innych rozbrat $\mathrm{z}$ naturalizmem metodologicznym, choć rzeczywisty, nie jest jeszcze dostrzeżony lub zrozumiany. Miejmy nadzieję, że te przykłady posłużą za punkt wyjścia dla dalszej eks ploracji nienaturalistycznych metodologii.

Jonathan Bartlett i Eric Holloway

\section{Bibliografia}

„Artificial Artificial Intelligence”, The Economist 8 January 2006, http://www.economist. com/node/7001738 (13.04.2017).

BAgus Phillip, „Methodological Naturalism in the Austrian School of Economics”, 2016 Conference on Alternatives to Methodological Naturalism 2016.

Bartlett Jonathan, „Measuring Software Complexity Using the Halting Problem”, w: Bartlett, Halsmer, and Hall (eds.), Engineering and the Ultimate..., s. 123-130. 
Bartlett Jonathan, „Using Turing Oracles in Cognitive Models of Problem-Solving”, w: Bartlett, Halsmer, and Hall (eds.), Engineering and the Ultimate..., s. 99-122.

Bartlett Jonathan, Halsmer Dominic, and Hall Mark (eds.), Engineering and the Ultimate: An Interdisciplinary Investigation of Order and Design in Nature and Craft, Blyth Institute Press, Broken Arrow, Oklahoma 2014.

Bolт Kristen Millares, „Amazon Creates Artificial Artificial Intelligence”, Seattle Pi 3 November 2005, http:/www.seattlepi.com/business/article/Amazon-creates-artificialartificialintelligence-1186698.php (13.04.2017).

DaI Peng, Mausam, and Weld Daniel S., „Artificial Intelligence for Artificial Artificial Intelligence", Proceedings of the Twenty-Fifth AAAI Conference on Artificial Intelligence 2011, https://www.aaai.org/ocs/index.php/AAAI/AAAI11/paper/viewFile/3775/4051 (13. 04.2017).

GILDER George, Knowledge and Power: The Information Theory of Capitalism and How It Is Revolutionizing our World, Regnery Publishing, Washington, DC. 2013.

Halsmer Dominic, Gewecke Michael, Gewecke Rachelle, Roman Nate, Todd Tyler, and FitzGerald Jessica, „Reversible Universe: Implications of Affordance-Based Reverse Engineering of Complex Natural Systems", w: Bartlett, Halsmer, and Hall (eds.), Engineering and the Ultimate..., s. 11-38.

Khatib Firas, DiMaio Frank, Cooper Seth, Kaźmierczyk Maciej, Gilski Mirosław, Krzywda Szymon, Zabrańska Helena, Pichova Iva, Thompson James, Popović Zoran, JAsKólski Mariusz, and BAKER David, „Crystal Structure of a Monomeric Retroviral Protease Solved by Protein Folding Game Players”, Nature Structural \& Molecular Biology 2011, vol. 18, no.10, s. 1175-1177.

Law Edith and von Ahn Luis, Human Computation, Morgan and Claypool 2011.

Marcus Adam and Parameswaran Aditya, „Crowdsourced Data Management: Industry and Academic Perspectives", Foundations and Trends in Databases 2015, vol. 6, no. 1-2, s. 1161.

Menger Carl, Investigations into the Method of the Social Sciences with Special Reference to Economics, trans. Francis J. Nock, New York University Press, New York and London (1883) 1985.

Nelson Paul, „Design Triangulation”, 2016 Conference on Alternatives to Methodological Naturalism 2016, film: https://www.youtube.com/watch?v=rNY_i1kJAnk (13.04.2017). 
RoberTson Douglas S., „Algorithmic Information Theory, Free Will, and the Turing Test”, Complexity 1999, vol. 4, no. 3, s. 17-34.

SAvitch Walter J., PASCAL: An Introduction to the Art and Science of Programming, Benjamin-Cummings Publishing Company, San Francisco 1984.

SEnor Dan and Singer Saul, Start-up Nation: The Story of Israel's Economic Miracle, Twelve, New York 2011.

Thiel Peter and Masters Blake, Zero to One: Notes on Startups, or How to Build the Future, Crown Business, New York 2014.

von Mises Ludwig, Ludzkie działanie. Traktat o ekonomii, przeł. Witold Falkowski, Biblioteka Klasyków Ekonomii, Instytut Ludwiga von Misesa, Warszawa 2007.

Woese Carl R., „A New Biology for a New Century”, Microbiology and Molecular Biology Reviews 2004, vol. 68, no. 2, s. 173-186.

\section{Nienaturalistyczne metodologie we współczesnej praktyce}

\section{Streszczenie}

W niektórych dziedzinach istnieją już alternatywy dla naturalizmu metodologicznego. Jednakże niewiele osób spoza danej dziedziny zna te alternatywy lub wie, jak są wykorzystywane. Niekiedy nawet sami przedstawiciele tych dziedzin stosują te nienaturalistyczne metodologie, nie wiedząc, że nie są one spójne z naturalizmem metodologicznym. W artykule dokonujemy krótkiego przeglądu dziedzin, w których — zgodnie z naszą wiedzą — występują metodologie niezależne od naturalizmu.

Slowa kluczowe: naturalizm metodologiczny, dualizm metodologiczny, austriacka ekonomia, ludzka komputacja, sztuczna sztuczna inteligencja, filozofia moralna, biologia systemowa, zasady inżynieryjne, inżynieria odwrotna.

\section{Non-Naturalistic Methodologies in Modern Practice}

\section{Summary}

Some fields already incorporate alternatives to methodological naturalism. However, few people outside the field are familiar with these alternatives or how they are used. Sometimes these non-naturalistic methodologies are being used without the participants' cognizance that the methodology is not methodologically naturalistic. Here, we show a smattering of fields that we are aware of that have touched upon methodologies that don't depend on naturalism. 
Keywords: methodological naturalism, methodological dualism, Austrian economics, human computation, artificial artificial intelligence, moral philosophy, systems biology, engineering principles, reverse engineering. 